\title{
Characteristics of Upper Permian oil shale and analysis of the resource development potential in the Lucaogou Formation in the Junggar Basin, northern Bogda Mountains, Northwest China
}

\author{
Yuanji Li ${ }^{(a, b, c)}$, Pingchang Sun $\left.{ }^{(a, b, c)}\right)^{*}$, Zhaojun Liu ${ }^{(a, b, c)}$, Liu Rong ${ }^{(a, b, c)}$, \\ Junxian Wang ${ }^{(\mathrm{a}, \mathrm{b})}$, Yue Li ${ }^{(\mathrm{a})}$, Meiqi Zhang ${ }^{(\mathrm{a}, \mathrm{b})}$
}

(a) College of Earth Sciences, Jilin University, Changchun, Jilin 130061, China

(b) Key-Lab for Oil Shale and Paragenetic Minerals of Jilin Province, Changchun, Jilin 130061, China

(c) Key Laboratory of Mineral Resources Evaluation in Northeast Asia, Ministry of Natural Resources, Changchun 130061, China

\begin{abstract}
Based on the results of exploration carried out from 2003 to 2017, oil shales from different areas of the Permian Lucaogou Formation in the Junggar Basin in the northern Bogda Mountains, Northwest China were comparatively investigated, their resources were summarized and development potential was analyzed. The layer of oil shale in the central region of the study area is the thickest, with the greatest cumulative thickness of $198.75 \mathrm{~m}$, while in the western and eastern regions the layer is relatively thin, $66.18 \mathrm{~m}$ and $130.00 \mathrm{~m}$, respectively. The total organic carbon (TOC) content of oil shale is 5-35 wt\%, whereas the average TOC of oil shale in the central and eastern regions is higher than that in the western region. Based on Hydrogen Index (HI)-Tmax and Pyrolytic Hydrocarbon $\left(S_{2}\right)$-TOC diagrams, the organic matter type of oil shale in the central region is mainly $I$, and in the western and eastern regions mostly $\mathrm{II}_{1}-\mathrm{II}_{2}$ and $\mathrm{I}-\mathrm{II}_{1}$, respectively. In the plane of the whole northern Bogda Mountains, the oil yield of oil shale greatly varies, and the quality of oil shale in the central region is the highest. Of all the studied samples, those with an oil yield $\omega>5 \mathrm{wt} \%$ account for $70 \%$. Oil shale resources in the study area total 55.241 billion tons (identified resources are 3.921 billion tons), while converted shale oil resources form 5.293 billion tons. Of the 55.241 billion tons, oil shale resources with an oil yield higher than $5 \mathrm{wt} \%$ account for 97.26\%. Analysis shows that the Yaomoshan Mountain mining area has the greatest development potential, followed by the Lucaogou and Shanghuangshanjie-Panjiazikou mining areas.
\end{abstract}

Keywords: Lucaogou Formation oil shale, Junggar Basin, identified resources, development potential.

\footnotetext{
* Corresponding author: e-mail sunpingchang711@126.com
} 


\section{Introduction}

Oil shale is an organic-rich, high-ash (> $40 \mathrm{wt} \%$ ), solid, combustible sedimentary rock that, upon low-temperature retorting, generally produces $\geq 3.5 \mathrm{wt} \%$ of oil. Its organic matter consists of sapropel, humosapropel or sapropel-humus and the calorific value is $>4.18 \mathrm{~kJ} / \mathrm{g}$. The lower limit of oil shale industrial acceptability (i.e. oil yield and calorific value) can vary as the economic conditions and technology for its development may be different [1]. Given the global shortage of energy and recovery of international oil prices since the beginning of the 21 st century, large oil shale resources available worldwide have become an important supplementary source of oil and gas [2-8].

Oil shale resources in China are widely distributed in 27 provinces and autonomous regions and 48 basins, with a total of 81 ore-bearing areas [1]. The nine major oil shale basins are: Songliao, Ordos, Lunpola, Junggar, Qiangtang, Qaidam, Maoming, Dayangshu and Fushun [9]. In 2003-2006, the oil shale resources of these basins totaled 719.9 billion tons, being equivalent to 47.6 billion tons of shale oil. The Junggar Basin comprised 54.99 billion tons of oil shale (45.9 million tons as identified resources), which, converted to 5.45 billion tons of shale oil resources, accounted for $11 \%$ of the total resources. So, the basin's potential for oil shale development is great.

Oil shale resources in the Junggar Basin are mainly enriched in the northern Bogda Mountains. In 2003-2006, the latter was divided into three mining areas: Yaomoshan, Lucaogou and Shuimogou, and one predicted area [1]. Further exploration over the past 10 years has led to the discovery of seven new mining areas in this region, namely Laobagou, Fukanglinchang, Shanghuangshanjie-Panjiazikou, Shichanggou, Mutasi, Wujiawan and Baiyanghe. Previous studies on oil shale sedimentary facies have established that oil shale in the mining areas of Yaomoshan, Lucaogou, Shuimogou, Laobagou and Fukanglinchang is deposited in shore-shallow to semi-deep lakes. Oil shale in the Shanghuangshanjie-Panjiazikou mining area is deposited in the center of a deep lake, while in those of Shichanggou, Mutasi, Wujiawan and Baiyanghe it is deposited in a semi-deep lake (Fig. 1a) [10]. Therefore, according to the stratum outcropping and sedimentary environment, oil shale mining areas in the northern Bogda Mountains are divided into the eastern region (Yaomoshan, Lucaogou, Shuimogou, Laobagou, Fukanglinchang, the predicted area), the central region (Shanghuangshanjie-Panjiazikou) and the western region (Shichanggou, Mutasi, Wujiawan, Baiyanghe). Based on collected bulk data, in this study, oil shales from different regions in the northern Bogda Mountains are comparatively characterized, their resources are summarized and prospects for oil shale development and utilization are analyzed. 


\section{Geological setting}

The Bogda Mountains are located in the eastern Tianshan Mountains along the southern edge of the Junggar Basin. This large foreland basin contains organicrich sediments [11-13]. A thick sequence of organic-rich oil shales deposited in a lacustrine setting is present in the basin [14]. Carroll et al. [15] identified three organic-rich oil shale formations in the Junggar Basin, from oldest to youngest: Jingjingzigou, Lucaogou and Hongyanchi, while the Lucaogou Formation oil shale is besides oil-prone (Fig. 1b). The strata in the study area are dominated by Upper Permian, Triassic, Early Jurassic and Cenozoic rocks [16-18]. Oil shale mainly occurs in the Upper Permian Lucaogou Formation, which comprises medium-to-fine sandstone, interbedded sandy shale and dolomitic limestone in addition. Based on lithological variability, there have been identified four lithologic sections, oil shale is mostly found in the second, third and fourth sections [9].

\section{Characteristics of oil shale}

\subsection{Physical characteristics}

The Lucaogou Formation oil shale in the Junggar Basin is predominantly gray, gray-brown, gray-black or black in colour. Oil shale with increased oil yield tends to be of lighter colour [9]. Oil shale with an oil yield $>10 \mathrm{wt} \%$ is gray-brown, and that with an oil yield of 3.5-5 wt\% is gray-black [19]. The thickness of the oil shale layer in the western region of the northern Bogda Mountains ranges from 24.73 to $66.18 \mathrm{~m}$ and its density is between 2.10 and $2.16 \mathrm{t} / \mathrm{m}^{3}$. The oil shale layer thickness in the central region is 17.60 $198.76 \mathrm{~m}$ and the density is $2.12-2.23 \mathrm{t} / \mathrm{m}^{3}$. In the eastern region of the northern Bogda Mountains the oil shale layer is $20.53-130.00 \mathrm{~m}$ thick and the density is $2.10-2.16 \mathrm{t} / \mathrm{m}^{3}$. So, there are huge, thick $(198.76 \mathrm{~m})$ oil shale deposits in the central region of the Junggar Basin, while in its eastern and western regions the deposits are of relatively small thickness (Table 1). However, the density of oil shale in the Bogda Mountains has remained largely unchanged (Table 1).

\subsection{Organic geochemistry}

Oil shale is a fine-grained sedimentary rock that is rich in organic matter and is mainly composed of $\mathrm{C}, \mathrm{H}, \mathrm{O}, \mathrm{N}$, and $\mathrm{S}$, as well as some minor elements. The total organic carbon (TOC) of oil shale in the northern Bogda Mountains is $5-34.75 \mathrm{wt} \%$, in the western region it is 5-19.7 wt\% (average $9.4 \mathrm{wt} \%$ ) and in the central and eastern regions respectively 5.86-32.23 $\mathrm{wt} \%$ (average $11.80 \mathrm{wt} \%$ ) and $5.78-34.75 \mathrm{wt} \%$ (average $9.8 \mathrm{wt} \%$ ). The vitrinite reflectance (Ro) of $0.6-1.13 \%$ and $T_{\max }$ of $433-454{ }^{\circ} \mathrm{C}$ indicate that oil shale in the study area is low-maturity to mature [22]. 

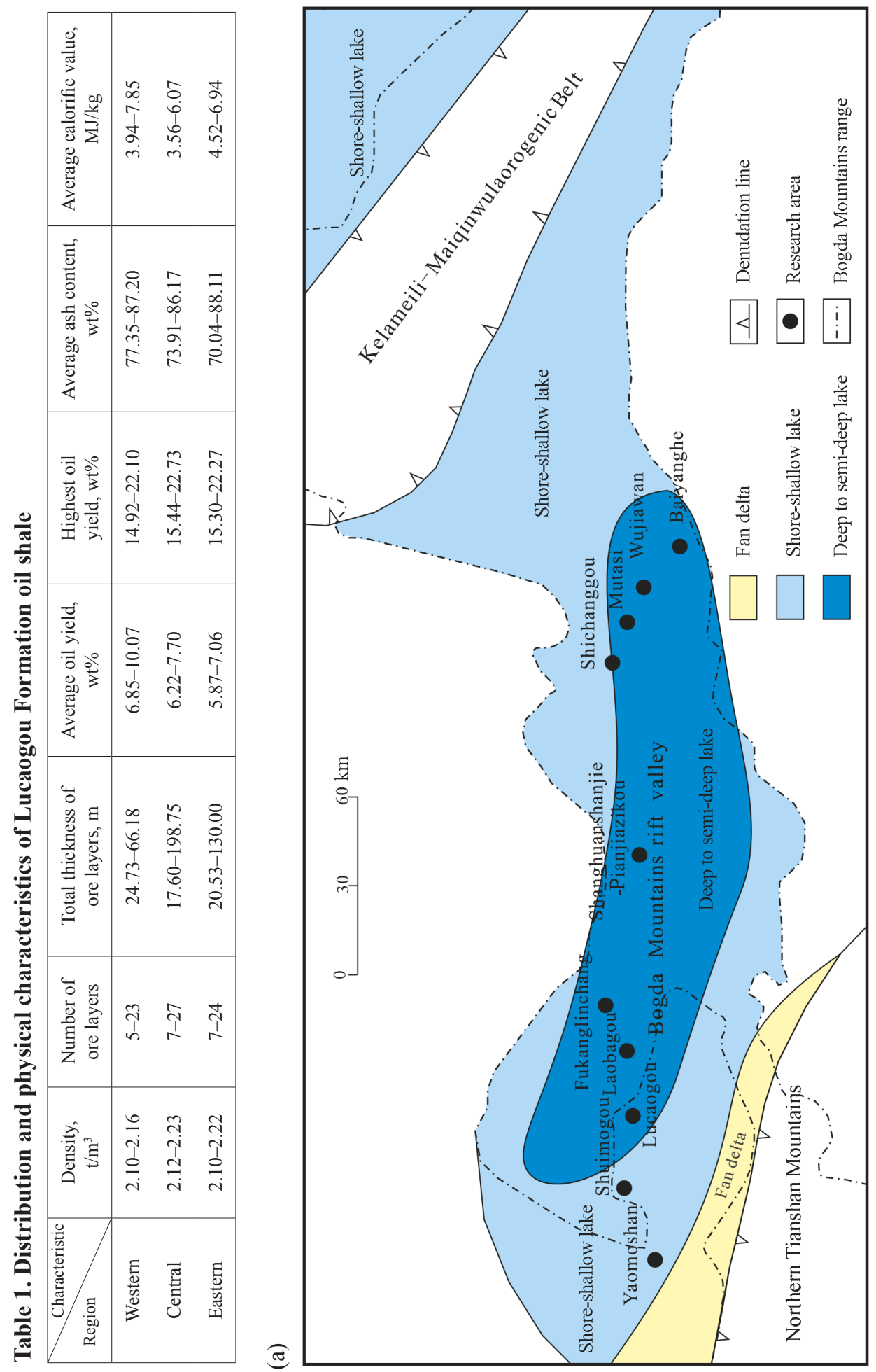


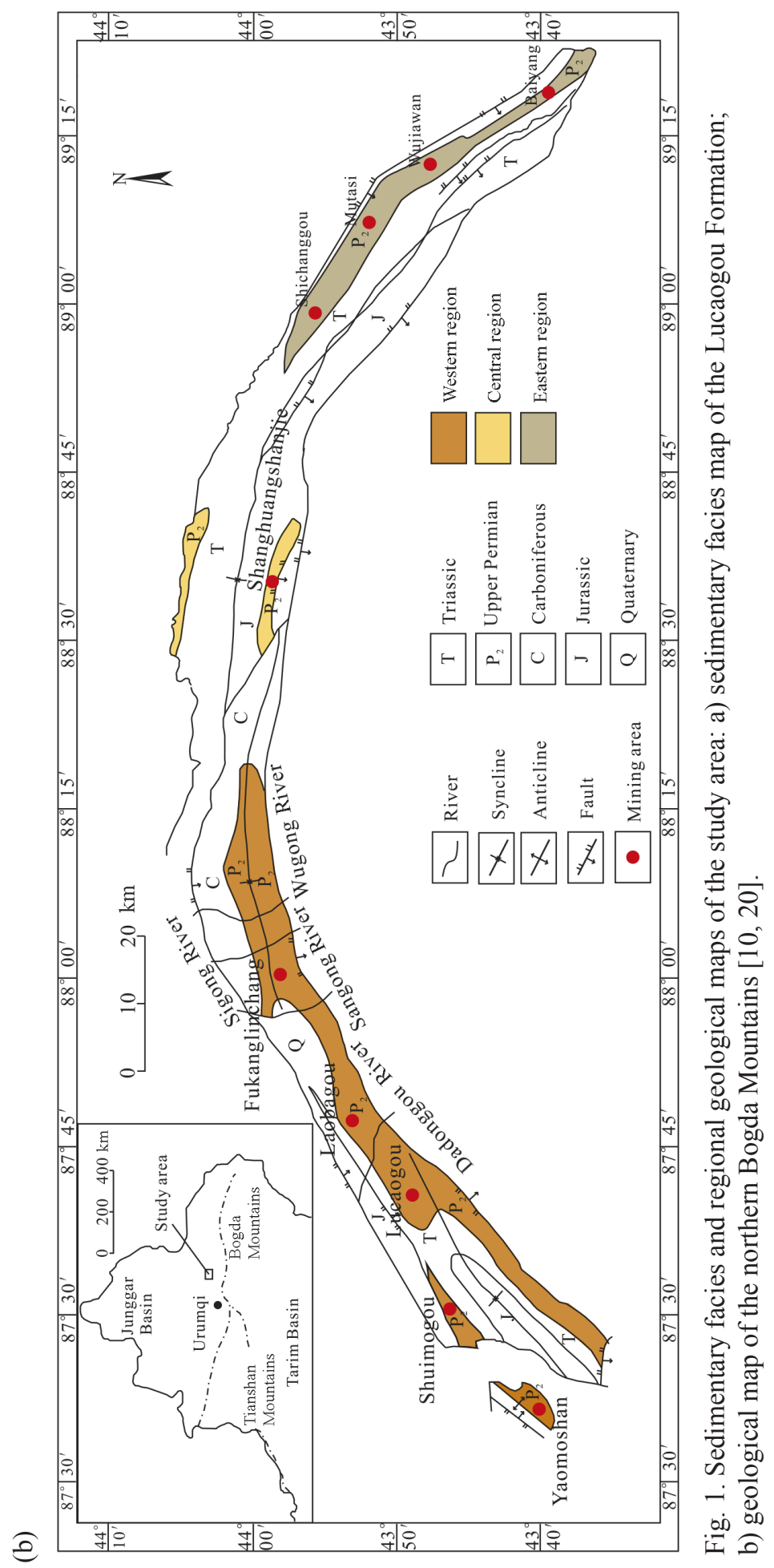




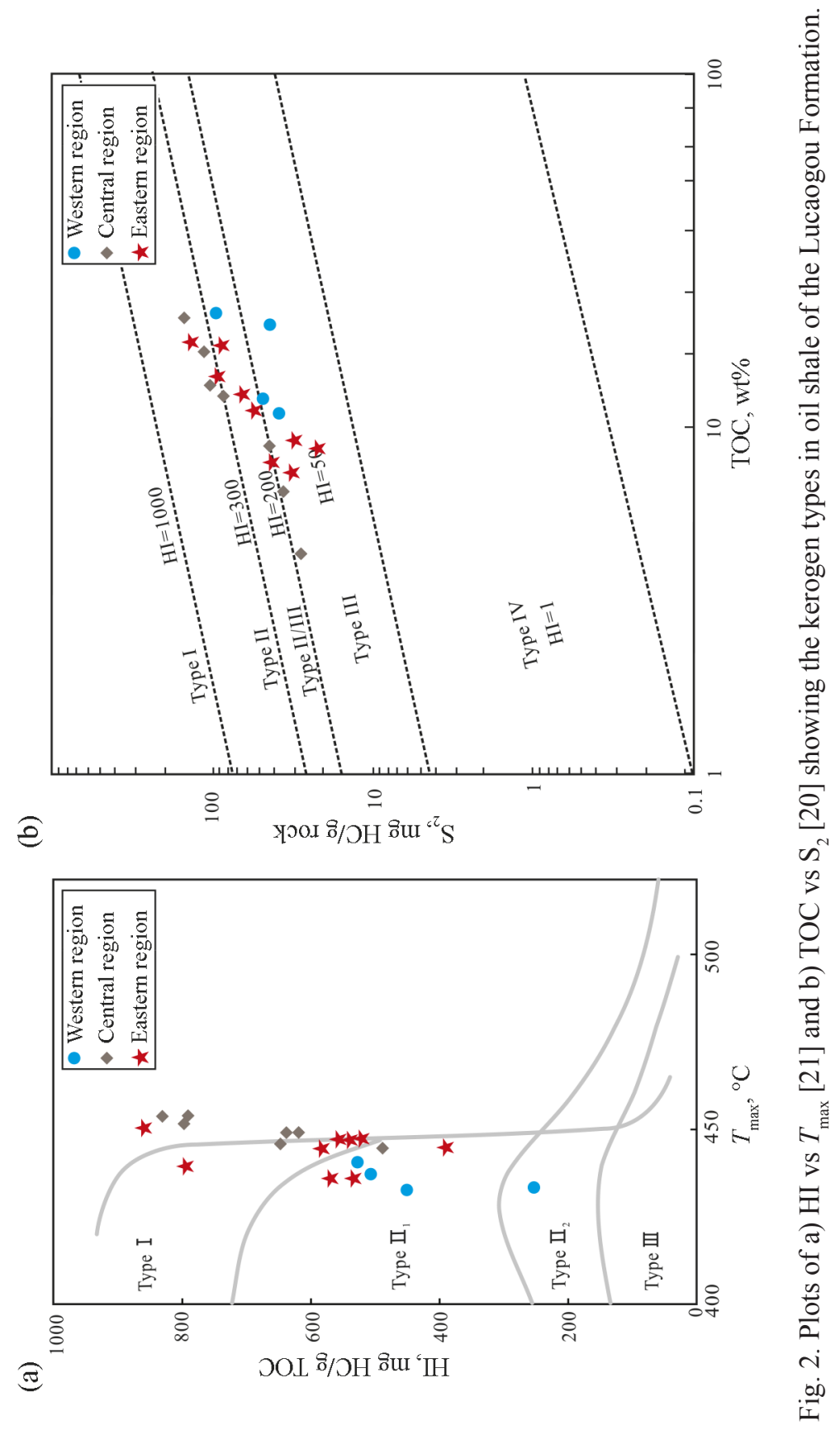


Statistical analysis shows the Hydrogen Index (HI) of oil shale in the western region of the northern Bogda Mountains to be $260-527 \mathrm{mg} / \mathrm{g}$ and pyrolytic hydrocarbon $\left(\mathrm{S}_{2}\right) 47.84-106.85 \mathrm{mg} / \mathrm{g}$, while these parameter values of oil shale in the central region are respectively $491-830 \mathrm{mg} / \mathrm{g}$ and 26.45 $167.63 \mathrm{mg} / \mathrm{g}$, and in the eastern region $215-859 \mathrm{mg} / \mathrm{g}$ and $12.43-145.23 \mathrm{mg} / \mathrm{g}$, respectively. According to $\mathrm{HI}-T$ max and $\mathrm{S}_{2}$-TOC diagrams, the organic matter type of oil shale in the central, eastern and western regions is respectively $\mathrm{II}_{1}-\mathrm{II}_{2}$, I and $\mathrm{I}-\mathrm{II}_{1}$ (Fig. 2a, 2b).

\subsection{Industrial quality characteristics}

\subsubsection{Oil yield}

Based on oil yield $(\omega)$, oil shale in the Junggar Basin was divided into three types: low-quality $(3.5 \mathrm{wt} \% \leq \omega \leq 5.0 \mathrm{wt} \%)$, medium-quality $(5 \mathrm{wt} \%<\omega \leq$ $10 \mathrm{wt} \%)$ and high-quality $(\omega>10 \mathrm{wt} \%)$ [1]. Oil shale in the basin's western region is mainly of medium quality, accounting for 71\%; high- and lowquality oil shales are less common, accounting for $19 \%$ and $10 \%$, respectively. Oil shale in the central area is chiefly of high or medium quality, accounting for $39 \%$ and $54 \%$, respectively, whereas low-quality oil shale accounts for only $7 \%$. The quality of oil shale in the eastern region is similar to that in the central region, high-, medium- and low-quality oil shales forming 32\%, 58\% and $10 \%$, respectively (Fig. 3). The above description is based on the analysis of data obtained from Xinjiang Baoming Mining Company.

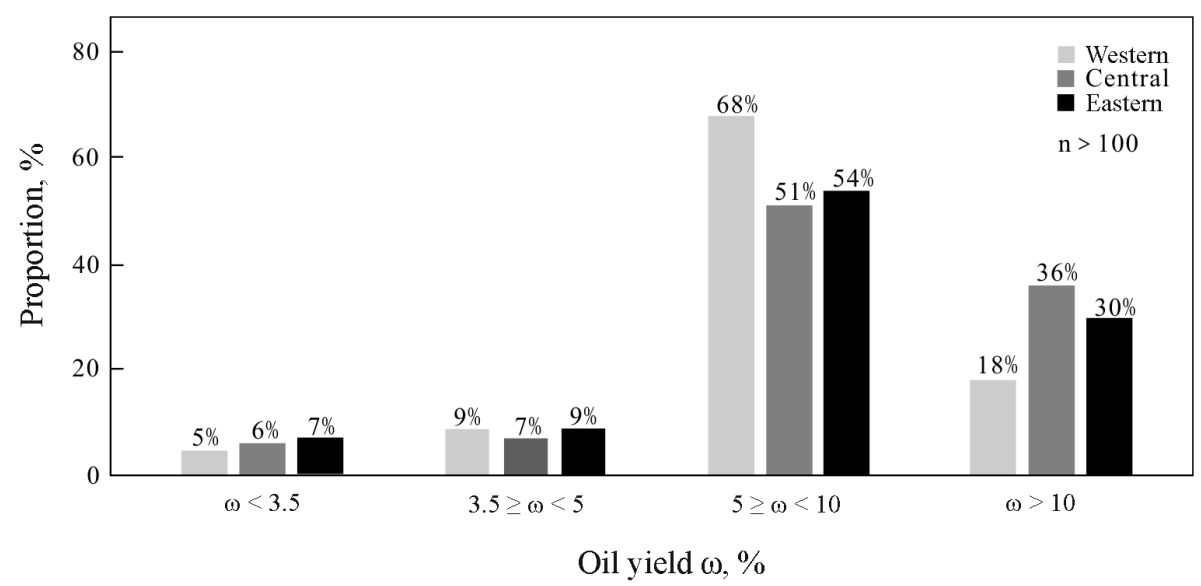

Fig. 3. Histogram of the oil yield from oil shale from the western, central and eastern regions in the Lucaogou Formation. 


\subsubsection{Calorific value}

Calorific value is an important index for evaluating the industrial quality and utilization of oil shale. The calorific value of oil shale in the western region of the Junggar Basin ranges from 3.94 to $6.07 \mathrm{MJ} / \mathrm{kg}$, in the central and eastern regions it varies between 3.56 and $7.85 \mathrm{MJ} / \mathrm{kg}$ and from 4.52 to $6.94 \mathrm{MJ} / \mathrm{kg}$, respectively. These values imply that the Junggar Basin oil shale is medium- or low-calorific. Its oil yield is positively correlated with calorific value, the correlation coefficient is 0.75 (Fig. 4a).

(a)

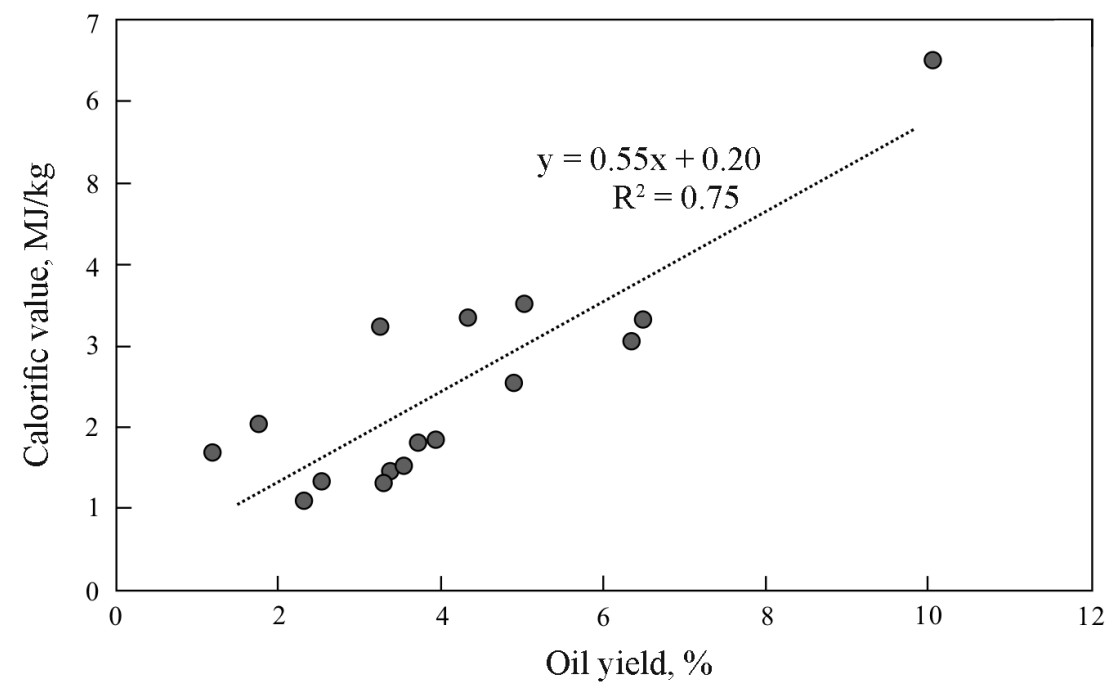

(b)

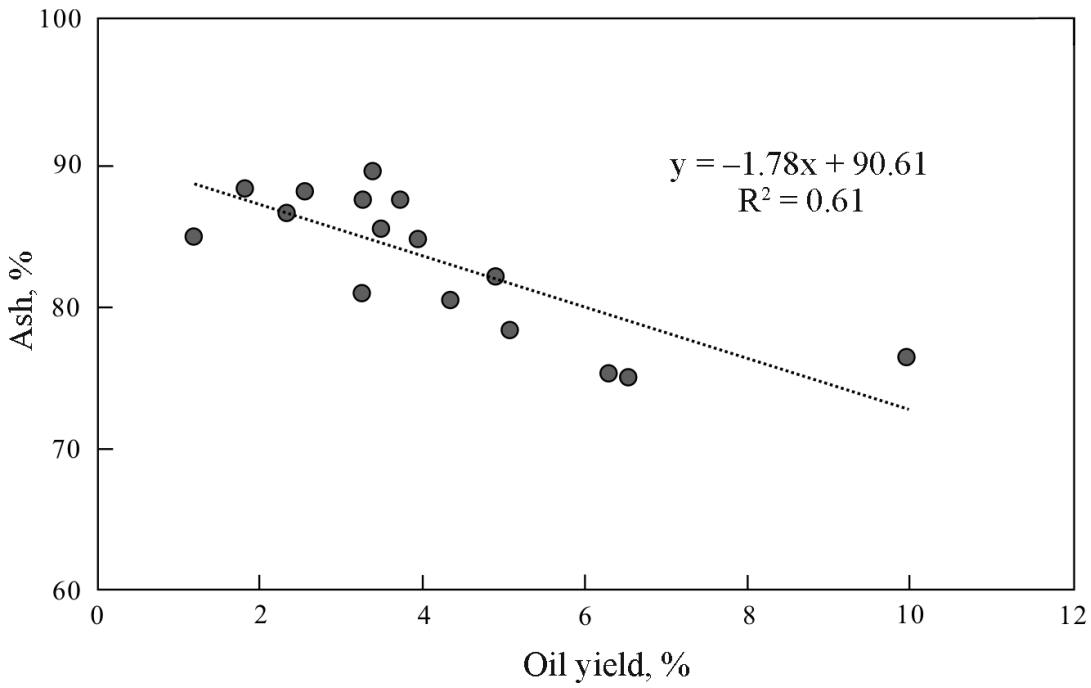

Fig. 4. Correlation plots of oil shale in the Lucaogou Formation: a) oil yield vs calorific value; b) oil yield vs ash. 


\subsubsection{Ash content}

Ash content is a key index to distinguish oil shale from coal and can be used to determine the quality of oil shale. Low-ash oil shale contains more organic matter. The ash content of oil shale in the Junggar Basin's western region is $77.35-87.20 \mathrm{wt} \%$ (average $79.45 \mathrm{wt} \%$ ), in the central region $73.91-86.17 \mathrm{wt} \%$ (average $77.32 \mathrm{wt} \%$ ) and in the eastern region 70.04-88.11 wt\% (average $80.61 \mathrm{wt} \%$ ). This indicates that oil shale in the study area is medium- or highash. Its oil yield is negatively correlated with ash content, the correlation coefficient is 0.61 (Fig. 4b).

\section{Resource evaluation and analysis of the development potential of the Junggar Basin}

From 2003 to 2006, oil shale resources in the Junggar Basin were evaluated for the first time in China. The evaluation area covered mainly the western region of the northern Bogda Mountains (Yaomoshan, Shuimogou and Lucaogou mining areas and the predicted area). The total evaluation area was $157.91 \mathrm{~km}^{2}$, of which the predicted area was $151.88 \mathrm{~km}^{2}$ and the exploration area was $6.03 \mathrm{~km}^{2}$. The assessment was based on China's classification criteria for solid mineral resources and reserves GB/T17766-1999 [23] and followed the coal resources assessment criteria [24]. The main resource evaluation methods used were the traditional volume method and geological analogy [25, 26]. The boundary evaluation parameters were: oil yield $\omega \geq 3.5 \mathrm{wt} \%$, burial depth $<1000 \mathrm{~m}$ and oil shale thickness $>0.7 \mathrm{~m}$.

Since 2006, there has been carried out extensive oil shale exploration work in the Junggar Basin, which has led to a significant re-estimation of resources. From 2006 to 2012, Xinjiang Baoming Mining Company carried out oil shale exploration in the eastern region of the northern Bogda Mountains. Four mining areas, namely Shichanggou, Mutasi, Wujiawan and Baiyanghe, were discovered and their resources were evaluated. In 2016, the 11th Geological Brigade of the Xinjiang Geological and Mineral Bureau carried out oil shale exploration in the central region of the northern Bogda Mountains and discovered the Shanghuangshanjie-Panjiazikou mining area. The results of new exploration work as well as evaluation data give evidence of that oil shale resources in the Junggar Basin are abundant and of good quality.

\subsection{Oil shale resources evaluation}

Oil shale in the Junggar Basin is concentrated in 11 mining areas located in the northern Bogda Mountains (Fig. 1b). Today the basin's oil shale resources are 55.24 billion tons, which is 441 million tons more than the amount evaluated in 2003-2006 (Table 2). The 55.24 billion tons include 4.36 billion tons of identified resources, which is 3.92 billion tons more than the amount estimated 
Table 2. Distribution of oil shale resources in the northern Bogda Mountains

\begin{tabular}{|l|c|c|c|c|c|c|}
\hline \multirow{2}{*}{ Region } & \multicolumn{3}{|c|}{ Oil shale, $10^{8} \mathrm{t}$} & \multicolumn{3}{c|}{ Shale oil, 108 ${ }^{8}$} \\
\cline { 2 - 7 } & $\begin{array}{c}\text { Estimated } \\
\text { total }\end{array}$ & $\begin{array}{c}\text { Discovered } \\
\text { resources }\end{array}$ & $\begin{array}{c}\text { Potential } \\
\text { resources }\end{array}$ & $\begin{array}{c}\text { Estimated } \\
\text { total }\end{array}$ & $\begin{array}{c}\text { Discovered } \\
\text { resources }\end{array}$ & $\begin{array}{c}\text { Potential } \\
\text { resources }\end{array}$ \\
\hline Western & 505.78 & 4.99 & 500.80 & 50.20 & 0.35 & 49.85 \\
Central & 33.76 & 25.78 & 7.97 & 1.93 & 1.53 & 0.40 \\
Eastern & 12.87 & 12.87 & 0 & 0.80 & 0.80 & 0 \\
Total & 552.41 & 43.64 & 508.77 & 52.93 & 2.68 & 50.25 \\
2003-2006 & 547.99 & 4.59 & 543.40 & 54.52 & 0.32 & 54.20 \\
\hline
\end{tabular}

in 2003-2006, as well as the predicted 50.87 billion tons, which is 3.463 billion tons less than the amount predicted in 2003-2006. Shale oil resources are 5.29 billion tons, which is 159 million tons less than the quantity evaluated in 2003-2006 (Table 2). This is due to the low accuracy of exploration in the Junggar Basin during that period. With increasing accuracy of oil shale exploration in recent years, part of the predicted area has become an identified area (Table 3), while the surface of the former has decreased from 151.88 to $140.88 \mathrm{~km}^{2}$. Thus, the basin's oil shale resources have decreased, as has the average oil yield of oil shale, namely from 10.07 to $7.10 \mathrm{wt} \%$ (Fig. 5). Although the degree of exploration has increased lately, the overall exploration level in the Junggar Basin is still very low, with only $7.90 \%$ of oil shale resources explored. In view of the great potential of oil shale resources in the study area, further exploration work is highly needed.

Oil shale resources in the northern Bogda Mountains are primarily distributed in the western and central regions. The western region's resources are 50.57 billion tons, which account for $91.56 \%$ of the total resources, 499 million tons are identified resources and 50.79 billion tons are predicted resources (Fig. 5). Oil shale resources in the central region are 3.376 billion tons and in the eastern region 12.87 million tons, making $6.11 \%$ and $2.33 \%$ of the total resources, respectively (Fig. 5).

Table 3. Grade distribution of oil shale resources in the northern Bogda Mountains

\begin{tabular}{|c|c|c|c|c|c|c|}
\hline \multirow{2}{*}{ Period } & \multicolumn{3}{|c|}{ Oil shale, $10^{8} \mathrm{t}$} & \multicolumn{3}{c|}{ Shale oil, $10^{8} \cdot \mathrm{t}$} \\
\cline { 2 - 7 } & $3.5-5 \mathrm{wt} \%$ & $5-10 \mathrm{wt} \%$ & $>10 \mathrm{wt} \%$ & $3.5-5 \mathrm{wt} \%$ & $5-10 \mathrm{wt} \%$ & $>10 \mathrm{wt} \%$ \\
\hline $2017-2019$ & 35.78 & 72.74 & 443.89 & 1.45 & 4.61 & 46.87 \\
\hline
\end{tabular}




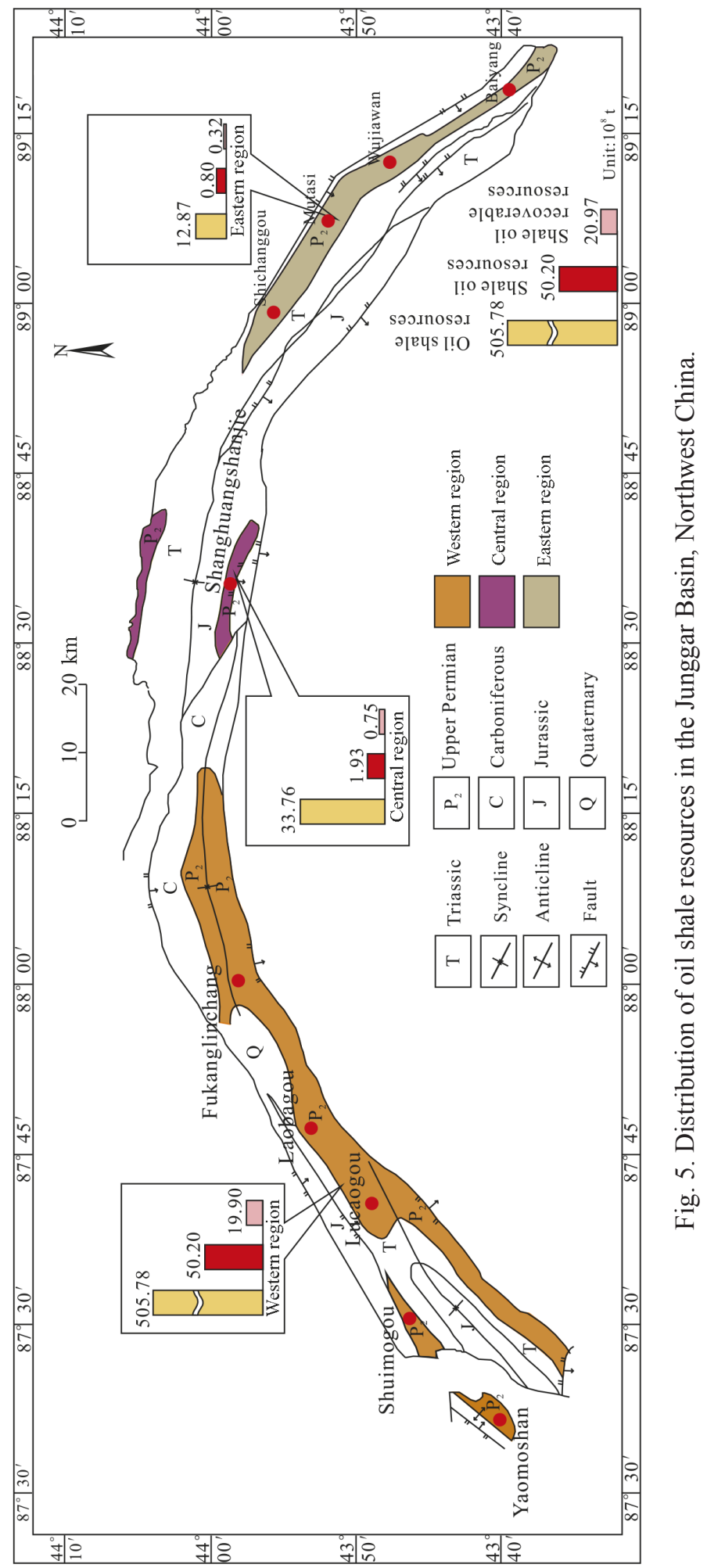




\subsection{Oil shale resources of different grades}

The classification of oil shale resources by oil yield is a useful basis for the rock development and utilization. In the Junggar Basin resources with an oil yield of $3.5-5 \mathrm{wt} \%$ form 3.57 billion tons, with 145 million tons of shale oil (converted from oil shale resources), accounting for $6.47 \%$ and $2.74 \%$ of the total resources, respectively. Resources with an oil yield of $5-10 \mathrm{wt} \%$ are 7.27 billion tons, with 461 million tons of shale oil, accounting for $13.16 \%$ and $8.71 \%$ of the total resources, respectively. 44.39 billion tons of oil shale resources, with an oil yield more than $10 \mathrm{wt} \%$, and 4.68 billion tons of shale oil account respectively for $80.37 \%$ and $88.55 \%$. In total, oil shale resources with an oil yield higher than $5 \mathrm{wt} \%$ account for $97.26 \%$ of the total oil shale resources in the Junggar Basin. These figures indicate that the basin's oil shale is of medium or high quality.

\subsection{Analysis of oil shale development potential}

Based on the data systematically collected from 10 mining areas (excluding the predicted mining area), the development sequence of these areas is optimized by further combining their topographic features, burial depth, cumulative thickness of ore layers, average oil yield, mining methods, and the reserves parameter scoring method (Table 4). The scoring parameters and criteria are preliminarily determined as follows:

Topography and landform: type I - plain, Loess Plateau (weight distribution (hereinafter wd) 1.00); type II - low mountains, hills, Gobi (wd 0.66); type III - desert, mountain, plateau (wd 0.33).

Burial depth of ore layer: type I - shallow (0-100 m; wd 1.00); type II medium (100-500 m; wd 0.66); type III - great (500-1000 m; wd 0.33).

Accumulative thickness of ore layer: oil shale ore layers are divided by thickness into thin (0.7-5 m; wd 0.25), medium-thick (5-10 m; wd 0.50), thick (10-50 m; wd 0.75) and super-thick (more than $50 \mathrm{~m}$; wd 1.00).

Average oil yield: according to oil yield, oil shale resources are divided into three grades: low-, medium- and high-grade with the respective distribution ranges of 3.5-5 wt\% (wd 0.33), 5-10 wt \% (wd 0.66) and > $10 \mathrm{wt} \%$ (wd 1.00).

Mining methods: open-pit mining (wd 1.00) and underground tunnel mining (wd 0.50).

Reserves: according to the classification standard of solid mineral resources and reserves [23], resources of an oil shale mining area are divided into large ( $>2$ billion tons; wd 1.00); medium ( $>2$ billion tons; wd 0.66 ) and small $(<200$ million tons; wd 0.33).

Environment: within the protected area (wd 0.00); outside the protected area (wd 1.00).

Based on the above parameters and the corresponding weight distributions, parameters of 10 mining areas are assigned and multiplied. As the multiplication result is too small, it is enlarged by 10,000 and sorted according to the obtained 


\begin{tabular}{|c|c|c|c|c|c|c|c|c|c|c|}
\hline 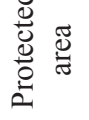 & $\stackrel{0}{\infty}$ & z & $\stackrel{\circ}{z}$ & $\stackrel{\circ}{z}$ & ż & z & $\stackrel{\circ}{z}$ & $\stackrel{\circ}{z}$ & $\stackrel{\circ}{z}$ & $\stackrel{\circ}{z}$ \\
\hline 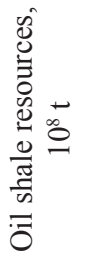 & ְ̊. & $\frac{1}{0}$ & $\begin{array}{l}\hat{b} \\
i\end{array}$ & $\hat{\theta}$ & $\vec{a}$ & $\begin{array}{l}\infty \\
\stackrel{\infty}{-}\end{array}$ & $\overrightarrow{\vec{i}}$ & $\underset{\sim}{\stackrel{q}{\sim}}$ & $\underset{\sim}{\stackrel{\infty}{\sim}}$ & $\begin{array}{l}\stackrel{0}{0} \\
\stackrel{0}{\sim}\end{array}$ \\
\hline 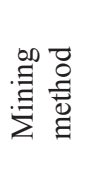 & $\begin{array}{l}: \overrightarrow{0} \\
\frac{1}{1} \\
0 \\
0 \\
0\end{array}$ & 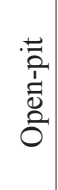 & 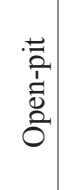 & 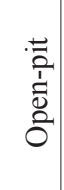 & $\begin{array}{l}\vec{\Xi} \\
\overline{0} \\
\bar{b} \\
\overrightarrow{0} \\
\vec{\sigma}\end{array}$ & 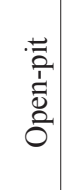 & $\begin{array}{l}\cdot \overrightarrow{0} \\
\frac{1}{1} \\
\frac{0}{0} \\
0 \\
0\end{array}$ & $\begin{array}{l}\overrightarrow{0} \\
\frac{0}{1} \\
\frac{0}{0} \\
0 \\
0\end{array}$ & 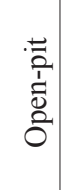 & 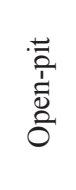 \\
\hline 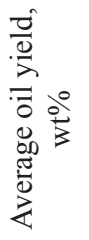 & $\stackrel{R}{0}$ & กิ & $\underset{\sim}{8}$ & $\begin{array}{l}n \\
\infty \\
0 \\
0\end{array}$ & $\stackrel{\text { }}{\circ}$ & $\tilde{\theta}_{0}^{0}$ & $\begin{array}{l}\hat{\infty} \\
\text { in }\end{array}$ & $\frac{0}{6}$ & 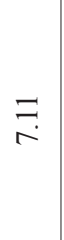 & $\stackrel{尺}{\stackrel{r}{r}}$ \\
\hline 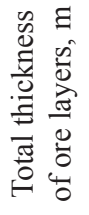 & $\begin{array}{l}8 \\
\stackrel{8}{0}\end{array}$ & $\begin{array}{l}8 \\
8 \\
8\end{array}$ & $\begin{array}{l}\vec{J} \\
m \\
n \\
n\end{array}$ & $\stackrel{\Re}{\stackrel{f}{f}}$ & $\begin{array}{l}\frac{\infty}{\overrightarrow{0}} \\
\stackrel{0}{0}\end{array}$ & $\begin{array}{l}\hat{n} \\
i n\end{array}$ & $\begin{array}{l}\tilde{O} \\
\dot{\infty} \\
\dot{\infty}\end{array}$ & $\begin{array}{l}\circ \\
\infty \\
\stackrel{0}{0}\end{array}$ & 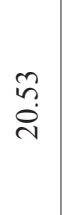 & $\begin{array}{l}\stackrel{0}{\mathfrak{n}} \\
\stackrel{\sim}{ \pm}\end{array}$ \\
\hline 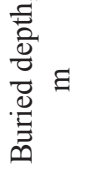 & $\begin{array}{l}8 \\
\stackrel{0}{0} \\
0\end{array}$ & $\begin{array}{l}8 \\
8 \\
0\end{array}$ & $\begin{array}{l}8 \\
\text { in } \\
0\end{array}$ & $\begin{array}{l}\stackrel{n}{n} \\
i \\
0\end{array}$ & $\begin{array}{l}8 \\
i \\
0\end{array}$ & $\begin{array}{l}8 \\
\stackrel{0}{1} \\
0\end{array}$ & 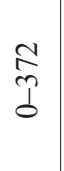 & $\frac{8}{8}$ & $\begin{array}{l}8 \\
8 \\
1 \\
0\end{array}$ & $\begin{array}{l}8 \\
8 \\
1 \\
0\end{array}$ \\
\hline 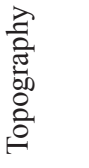 & 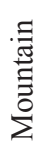 & 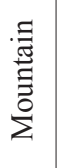 & 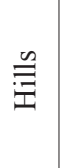 & 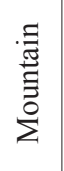 & $\begin{array}{l}\text {. } \\
\stackrel{\Xi}{\Xi} \\
\stackrel{\Xi}{\Sigma}\end{array}$ & 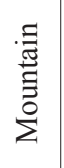 & $\begin{array}{l}\stackrel{\Xi}{\Xi} \\
\stackrel{\Xi}{\Xi} \\
\stackrel{\Xi}{\Sigma}\end{array}$ & 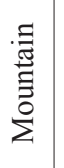 & 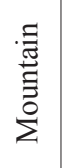 & 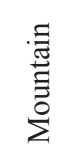 \\
\hline 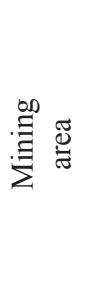 & 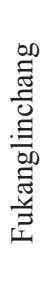 & 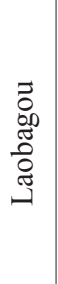 & 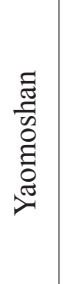 & 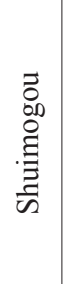 & $\begin{array}{l}\overrightarrow{0} \\
0 \\
0 \\
0 \\
0 \\
\Xi \\
\Xi\end{array}$ & 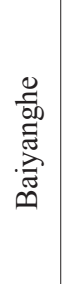 & 离 & : & 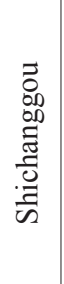 & 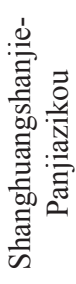 \\
\hline 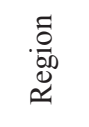 & \multicolumn{5}{|c|}{ 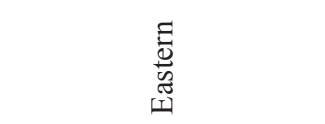 } & \multicolumn{4}{|c|}{$\sum_{3}^{0}$} & 苛 \\
\hline
\end{tabular}




\begin{tabular}{|c|c|c|c|c|c|c|c|c|c|c|}
\hline 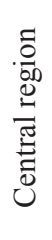 & 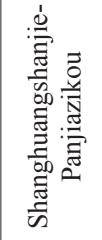 & $\stackrel{m}{3}$ & $\stackrel{m}{3}$ & - & $\begin{array}{l}: \\
:\end{array}$ & - & - & - & $\stackrel{\infty}{i}$ & $m$ \\
\hline \multirow{4}{*}{ 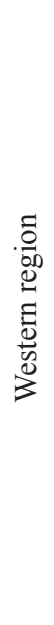 } & 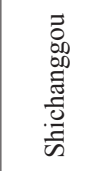 & $\stackrel{m}{0}$ & $\stackrel{m}{0}$ & $\frac{n}{0}$ & $\begin{array}{l}0 \\
\stackrel{0}{0}\end{array}$ & - & $\stackrel{\bullet}{\circ}$ & - & $\begin{array}{l}\infty \\
n \\
n \\
n\end{array}$ & in \\
\hline & 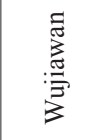 & $\stackrel{m}{0}$ & $\stackrel{m}{0}$ & - & $\begin{array}{l}: \\
0 \\
0\end{array}$ & - & $\stackrel{\bullet}{\stackrel{0}{0}}$ & - & 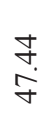 & $\nabla$ \\
\hline & 䔅 & $\stackrel{m}{?}$ & $\stackrel{n}{0}$ & - & $\begin{array}{l}: \\
0\end{array}$ & - & $\stackrel{\bullet}{\circ}$ & - & 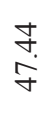 & $\nabla$ \\
\hline & 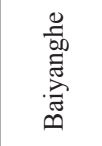 & $\tilde{n}$ & $\begin{array}{l}0 \\
0 \\
0\end{array}$ & - & $\begin{array}{l}: \\
\stackrel{0}{0}\end{array}$ & - & $\tilde{\overbrace{}}$ & - & $\begin{array}{l}\underset{f}{+} \\
\stackrel{f}{f}\end{array}$ & $\nabla$ \\
\hline \multirow{5}{*}{ 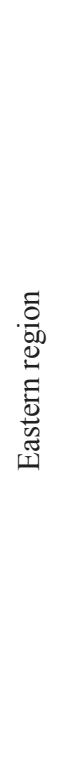 } & $\begin{array}{l}\vec{\Xi} \\
8 \\
0 \\
\tilde{\Xi} \\
\Xi \\
\Xi\end{array}$ & $\stackrel{m}{0}$ & $\stackrel{8}{:}$ & - & $\begin{array}{l}: \\
0 \\
0\end{array}$ & - & $\stackrel{\bullet}{0}$ & - & 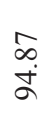 & N \\
\hline & 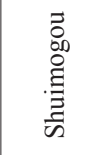 & $\stackrel{m}{0}$ & $\stackrel{8}{\circ}$ & $\stackrel{n}{0}$ & $\begin{array}{l}: \\
0 \\
0\end{array}$ & $\tilde{0}$ & $\stackrel{m}{0}$ & - & 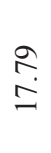 & 0 \\
\hline & 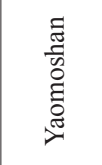 & $\stackrel{\bullet}{:}$ & $\stackrel{8}{:}$ & - & $\begin{array}{l}: \\
0 \\
0\end{array}$ & - & $\stackrel{\bullet}{:}$ & - & $\begin{array}{l}n \\
\stackrel{\infty}{\infty} \\
\infty\end{array}$ & - \\
\hline & 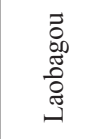 & $\stackrel{m}{?}$ & $\begin{array}{l}8 \\
:\end{array}$ & - & $\begin{array}{l}8 \\
:\end{array}$ & - & $\stackrel{m}{?}$ & - & $\begin{array}{l}\underset{f}{f} \\
\text { f }\end{array}$ & $\nabla$ \\
\hline & 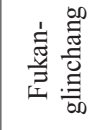 & $\stackrel{m}{0}$ & $\begin{array}{l}8 \\
:\end{array}$ & - & $\begin{array}{l}0 \\
: \\
0\end{array}$ & - & $\stackrel{m}{3}$ & 0 & 0 & $r$ \\
\hline & 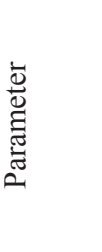 & 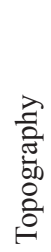 & 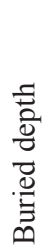 & 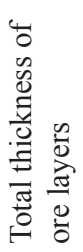 & 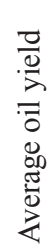 & 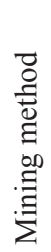 & $\begin{array}{l}\tilde{d} \\
0 \\
0 \\
0 \\
0 \\
0 \\
0 \\
\frac{0}{\pi} \\
\frac{\pi}{n} \\
\overline{0}\end{array}$ & 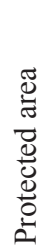 & 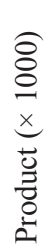 & 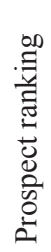 \\
\hline
\end{tabular}


values. The results of assignment presented in Table 5 show the development potential of the Yaomoshan mining area to be the highest, followed by the Lucaogou and Shanghuangshanjie-Panjiazikou mining areas, while that of the remaining six mining areas is low. Due to environmental requirements, the Fukanglinchang mining area was rejected by one vote.

\section{Conclusions}

Based on the analysis of physical characteristics, organic matter type, industrial quality and resource development potential of oil shale in the northern Bogda Mountains, the following conclusions are drawn:

1. Oil shale in the Lucaogou Formation is mainly gray, gray-brown, grayblack or black in colour. The oil shale layer is very thick, especially in the central region where it may reach $198.75 \mathrm{~m}$. At the same time, in the western and eastern regions it is relatively thin, $66.18 \mathrm{~m}$ and $130.00 \mathrm{~m}$, respectively. The density of oil shale varies slightly, from 2.10 to $2.16 \mathrm{t} / \mathrm{m}^{3}$.

2. The total organic carbon content of oil shale ranges from 5 to $34.75 \mathrm{wt} \%$. In the central and eastern regions the total organic carbon content is $5-34.75 \mathrm{wt} \%$, in the western region $519.7 \mathrm{wt} \%$. The organic matter type of oil shale in the central, eastern and western regions is mainly $\mathrm{II}_{1}-\mathrm{II}_{2}$, I and $\mathrm{I}-\mathrm{II}_{1}$, respectively.

3. The oil yield of oil shale in the study area varies greatly by region. Oil shale in the central region is of the highest quality, with $70 \%$ of the samples having an oil yield $\omega>5 \mathrm{wt} \%$. The ash content of oil shale is between 70.04 and $88.11 \mathrm{wt} \%$ and its calorific value is $3.56-7.85 \mathrm{MJ} / \mathrm{kg}$. It belongs to medium-low calorific and medium-high ash oil shales.

4. Based on the latest exploration results, oil shale resources in the study area are 5.54 billion tons (3.92 billion tons as identified resources) and resources converted into synthetic shale oil resources are 5.29 billion tons. Oil shale resources with an oil yield higher than $5 \mathrm{wt} \%$ account for $97.26 \%$ of the total resources, which indicates that oil shale in the Junggar Basin is of medium or high quality.

5. Analysis shows the Yaomoshan mining area in the northern Bogda Mountains to have the greatest development potential, followed by the Lucaogou and Shanghuangshanjie-Panjiazikou mining areas. Due to environmental requirements, the Fukanglinchang mining area was rejected by one vote.

\section{Acknowledgements}

The authors would like to thank the National Natural Science Foundation of China (41772092, 41420088) and the Self-determined Foundation of Key Laboratory of Mineral Resources Evaluation in Northeast Asia, Ministry of 
Natural Resources (DBY-ZZ-19-05). We are very grateful to two anonymous reviewers for their valuable comments.

\section{REFERENCES}

1. Liu, Z. J., Yang, H. L., Dong, Q. S., Zhu, J. W., Guo, W., Ye, S. Q., Liu, R., Meng, Q. T., Zhang, H. L., Gan, S. C. Oil Shale in China. Petroleum Industry Press, Beijing, 2009, 62-116 (in Chinese, summary in English).

2. Qian, J. L., Yin, L. Oil Shale - Petroleum Alternative. China Petrochemical Press, Beijing, 2011, 1-50.

3. Brendow, K. Global oil shale issues and perspectives. Oil Shale, 2003, 20(1), 81-92.

4. Hilger, J. Combined utilization of oil shale energy and oil shale minerals within the production of cement and other hydraulic binders. Oil Shale, 2003, 20(3S), 347-355.

5. Hou, J. L., Ma, Y., Li, S. Y., Teng, J. S. Development and utilization of oil shale worldwide. Chemical Industry and Engineering Progress, 2015, 34(5), 11831190 (in Chinese, summary in English).

6. An, B. C., Wang, W. Y., Ji, G. J., Gan, S. C., Gao, G. M., Xu, J. J., Li, G. H. Preparation of nano-sized $\alpha-\mathrm{Al}_{2} \mathrm{O}_{3}$ from oil shale ash. Energy, 2010, 35(1), 45-49.

7. Zhang, Z. K., Zhang, L., Li, A. M. Remedial processing of oil shale fly ash (OSFA) and its value-added conversion into glass-ceramics. Waste Manage., 2015, 46, 316-321.

8. Vallner, L., Gavrilova, O., Vilu, R. Environmental risks and problems of the optimal management of an oil shale semi-coke and ash landfill in Kohtla-Järve, Estonia. Sci. Total Environ., 2015, 524-525, 400-415.

9. Liu, Z. J., Meng, Q. T., Dong, Q. S., Zhu, J. W., Guo, W., Ye, S. Q., Liu, R., Jia, J. L. Characteristics and resource potential of oil shale in China. Oil Shale, 2017, 34(1), 15-41.

10. Lu, M. A. Multistage Evolution of the Basin-and-Range Structure of the Eastern Section of the Tianshan Mountains. Ph.D. Dissertation, Institute of Geology, China Earthquake Administration, 2007, 410 pp (in Chinese, summary in English).

11. Tao, S., Tang, D. Z., Li, J. J., Xu, H., Li, S., Chen, X. Z. Indexes in evaluating the grade of Bogda Mountain oil shale in China. Oil Shale, 2010, 27(2), 179-189.

12. Tao, S., Tang, D. Z., Xu, H., Cai, J. L., Gou, M. F., Chen, Z. L. Retorting properties of oil shale found at the northern foot of Bogda Mountain, China. Oil Shale, 2011, 28(1), 19-28.

13. Tao, S., Tang, D. Z., Xu, H., Liang, J. L., Shi, X. F. Organic geochemistry and elements distribution in Dahuangshan oil shale, southern Junggar Basin: Origin of organic matter and depositional environment. Int. J. Coal Geol., 2013, 115, 41-51.

14. Carroll, A. R., Bohacs, K. M. Stratigraphic classification of ancient lakes: bal- 
ancing tectonic and climatic controls. Geology, 1999, 27(2), 99-102.

15. Carroll, A. R., Brassell, S. C., Graham, S. A. Upper Permian lacustrine oil shales, southern Junggar Basin, northwest China. AAPG Bull., 1992, 76, 1874-1902.

16. Tao, S., Wang, Y. B., Tang, D. Z., Wu, D. M., Xu, H., He, W. Organic petrology of Fukang Permian Lucaogou Formation oil shales at the northern foot of Bogda Mountain, Junggar Basin, China. Int. J. Coal Geol., 2012, 99, 27-34.

17. Tao, S., Wang, Y. B., Tang, D. Z., Xu, H., Zhang, B., Deng, C. M., He, W. Estimation of the mineable oil shale amount in West Fukang at the northern foot of Bogda Mountain, Zhunggar Basin, China. Energ. Source. Part A, 2012, 34(19), 1791-1800.

18. Tao, S., Wang, Y. B., Tang, D. Z., Xu, H., Zhang, B., He, W., Liu, C. Composition of the organic constituents of Dahuangshan oil shale at the northern foot of Bogda Mountain, China. Oil Shale, 2012, 29(2), 115-127.

19. Tao, S., Shan, Y. S., Tang, D. Z., Xu, H., Li, S., Cui, Y. Mineralogy, major and trace element geochemistry of Shichanggou oil shales, Jimusaer, Southern Junggar Basin, China: Implications for provenance, palaeoenvironment and tectonic setting. J. P. Sci. Eng., 2016, 146, 432-445.

20. Espitalié, J., Marquis, F., Barsony, I. Geochemical logging. In: Analytical Pyrolysis - Techniques and Applications (Voorhees, K. J., ed.), Butterworths, Boston, 1984, 53-79.

21. Espitalié, J., Laporte, J. L., Madec, M., Marquis, F., Leplat, P., Paulet, J., Boutefeu, A. Méthode rapide de caractérisation des roches mères, de leur potentiel pétrolier et de leur degré d'évolution. Rev. I. Fr. Pétrol., 1977, 32(1), 23-42 (in French).

22. Li, Y. J., Sun, P. C., Liu, Z. J., Wang, J. X., Li, Y., Zhang, M. Q. Lake level controls on oil shale distribution in the Lucaogou Formation, Wujiawan Area, Junggar Basin, northwest China. Energ. Fuel., 2019, 33(9), 8383-8393.

23. National Quality and Technique Supervise Office. GB/T17766-1999, National Criterion of P. R. China. Solid Mineral Resource/Reserves Classification. Standards Press of China, Beijing, 1999, 3-5 (in Chinese).

24. National Quality Supervision and Quarantines Office. GB/T13908-2002, Solid Mineral Geological Survey Criterion, General Rules. Standards Press of China, Beijing, 2002, 1-14 (in Chinese).

25. Jia, J. L., Liu, Z. J., Meng, Q. T., Liu, R., Sun, P. C., Chen, Y. C. Quantitative evaluation of oil shale based on well log and 3-D seismic technique in the Songliao Basin, Northeast China. Oil Shale, 2012, 29(2), 128-150.

26. Jia, J. L., Liu, Z. J., Liu, R., Guo, W., Chen, H. J., Sun, P. C., Meng, Q. T. Establishment of assessment system for oil shale resources based on geological analogy. Acta Geologica Sinica, 2014, 88(7), 1321-1333 (in Chinese, summary in English).

Presented by A. Soesoo

Received June 25, 2019 